\section{Synthesis of new composite materials for processing of methane into important petrochemical products}

1,2Kaumenova G.N., ${ }^{1,3}$ Zhumabek M., ${ }^{1}$ Abilmagzhanov A.Z., ${ }^{2}$ Aubakirov Y.A.

${ }^{1}$ Komashko L.V., ${ }^{1,2}$ Tungatarova S.A., ${ }_{1,2}$ Baizhumanova T.S.*

${ }^{1}$ D.V. Sokolsky Institute of Fuel, Catalysis and Electrochemistry, Almaty, Kazakhstan ${ }^{2}$ Al-Farabi Kazakh National University, Almaty, Kazakhstan ${ }^{3}$ Satbayev University, Almaty, Kazakhstan *E-mail: baizhuma@mail.ru
The aim of this research was to develop the technology of new composite material synthesis for the processing of natural gas methane into olefins. The effects of technological parameters (temperature, volumetric rate, reaction mixture composition) on methane's oxidative conversion into important petrochemical products has been studied. The paper presents data on methods developed for synthesis and physicochemical characteristics of catalysts. The technological parameters of the process conducted by means of integrated automated laboratory setup were optimized. It has been established that $10 \% \mathrm{~K}-30 \% \mathrm{Mn}-10 \% \mathrm{Nb} / 50 \%$ glycine catalyst prepared by the solution combustion synthesis (SHS) method in solution was active for olefin formation at oxidative transformation of mixture $41.8 \% \mathrm{CH}_{4}+16.2 \% \mathrm{O}_{2}+42 \% \mathrm{Ar}$ at a volumetric velocity of $3500 \mathrm{~h}^{-1}$. It was determined that at $\mathrm{T}=800^{\circ} \mathrm{C}$, yields of $\mathrm{C}_{2}^{2} \mathrm{H}_{6}$ and $\mathrm{C}_{2} \mathrm{H}_{4}$ were 3.3 and $14.3 \%$, respectively.

Keywords: methane; catalytic oxidation; solution combustion synthesis; ethylene; hydrogen.

\section{Метанды маңызды мұнайхимиялық, өнімдерге қайта өңдеуде жаңа композитті материалдарды синтездеу}

\footnotetext{
1,2Кауменова Г.Н., 1,3 Жумабек М. ${ }^{1}$ Абильмагжанов А.З., ${ }^{2}$ Аубакиров Е.А. ${ }^{1}$ Комашко Л.В., ${ }^{1,2}$ Тунгатарова С.А. 1,2Байжуманова Т.C *

${ }^{1}$ Д.В. Сокольский атындағы Жанармай, катализ және электрохимия институты, Алматы, Қазақстан

əл-Фараби атындағы Қазақ ұлттық университеті, Алматы, Қазақстан ${ }^{3}$ Сәтбаев университеті, Алматы, Қазақстан *E-mail: baizhuma@mail.ru
}

Зерттеу мақсаты метанды маңызды мұнайхимиялық өнімдерге қайта өңдеуде жаңа композитті материалдарды синтездеу болып табылады. Метанның маңызды мұнайхимиялық өнімдерге тотыға айналу реакциясының технологиялық параметрлерінің (температура, көлемдік жылдамдық, реакциялық қоспаның құрамы) әсері зерттелінді. Мақалада дайындалған катализаторлардың синтездеу әдістері мен физика-химиялық қасиеттері ұсынылған. Автоматтандырылған зертханалық қондырғыда үрдістің технологиялық параметрлері оңтайландырылған. Ерітіндіде өздігінен таралатын жоғарь температуралы синтез (ӨтЖТС) әдісімен 10\% K-30\% Mn- $10 \%$ Nb/50\% глицин дайындалған катализаторда бастапқы реакциялық қоспа 41,8\% $\mathrm{CH}_{4}+16,2 \% \mathrm{O}_{2}+42 \% \mathrm{Ar}$, көлемдік жылдамдығы 3500 сағ $^{-1}$ тотықтырғанда олефиндердің түзілу белсенділігі анықталынды. Зерттеу нәтижелері $\mathrm{T}=800^{\circ} \mathrm{C}$ кезінде $\mathrm{C}_{2} \mathrm{H}_{6}$ және $\mathrm{C}_{2} \mathrm{H}_{4}$ шығымдары 3,3\% және $14,3 \%$ құрайтынь анықталынды.

Түйін сөздер: метан; катализдік тотығу; өздігінен таралатын жоғары температуралы синтез; этилен; сүтегі.

\section{Синтез новых композиционных материалов для переработки метана в важные нефтехимические продукты}

1,2Кауменова Г.Н., 1,3Жумабек М. ${ }^{1}$ Абильмагжанов А.3. ${ }^{2}$ Аубакиров Е.А ${ }^{1}$ Комашко Л.В., ${ }^{1,2}$ Тунгатарова С.А. 1,2Байжуманова Т.C.*

${ }^{1}$ Институт топлива, катализа и электрохимии имени Д.В. Сокольского Алматы, Казахстан ${ }^{2}$ Казахский национальный университет имени аль-Фараби, Алматы, Казахстан Университет Сатпаева, Алматы, Казахстан

*E-mail: baizhuma@mail.ru
Целью данного исследования было разработать технологию синтеза новых композиционных материалов для переработки метана в важные нефтехимические продукты. Исследовано влияние технологических параметров (температуры, объемной скорости, состава реакционной смеси) реакции окислительного превращения метана в важные нефтехимические продукты. В статье представлены данные разработанных методов синтеза и установлены физико-химические характеристики катализаторов. Оптимизированы технологические параметры процесса, проведенного на автоматизированной лабораторной установке. Установлено, что активным по образованию олефинов при окислительном превращении смеси 41,8\% CH +16,2\% O +42\% Ar при объемной скорости 3500 ч $^{-1}$ является $10 \% \mathrm{~K}-30 \% \mathrm{Mn}-10 \% \mathrm{Nb} / 50 \%$ глицин катализатор, приготовленный мметодом самораспростроняющегося высокотемпературного синтеза (CBC) в растворе. Определено, что при $\mathrm{T}=800^{\circ} \mathrm{C}$ выход $\mathrm{C}_{2} \mathrm{H}_{6}$ и $\mathrm{C}_{2} \mathrm{H}_{4}$ составляет $3,3 \%$ и $14,3 \%$, соответственно.

Ключевые слова: метан; каталитическое окисление; самораспространяющийся высокотемпературный синтез; этилен; водород. 


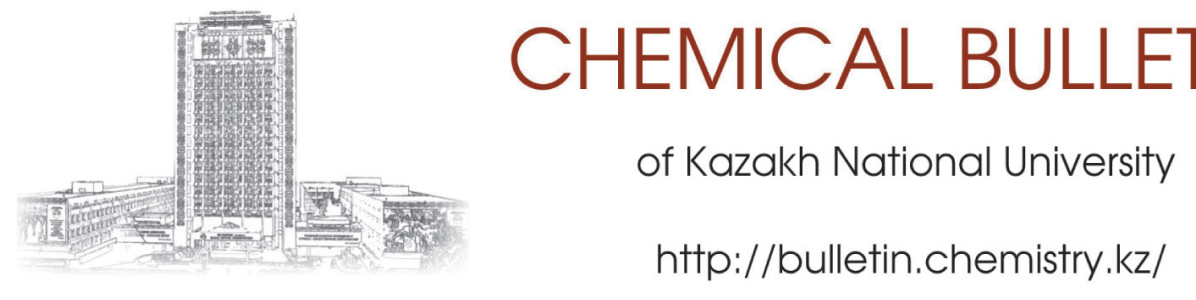

\title{
Synthesis of new composite materials for processing of methane into important petrochemical products
}

\author{
${ }^{1,2}$ Kaumenova G.N., ${ }^{1,3}$ Zhumabek M., ${ }^{1}$ Abilmagzhanov A.Z., \\ ${ }^{2}$ Aubakirov Y.A., ${ }^{1}$ Komashko L.V., ${ }^{1,2}$ Tungatarova S.A., ${ }^{1,2}$ Baizhumanova T.S.* \\ ${ }^{1}$ D.V. Sokolsky Institute of Fuel, Catalysis and Electrochemistry, Almaty, Kazakhstan \\ ${ }^{2} \mathrm{Al}-$ Farabi Kazakh National University, Almaty, Kazakhstan \\ ${ }^{3}$ Satbayev University, Almaty, Kazakhstan \\ *E-mail: baizhuma@mail.ru
}

\section{Introduction}

The world's oil reserves are decreasing every day due to the continuous production and their processing using the most modern technologies. Scientists all over the world are looking for various raw materials and methods to use the vast resources of natural gas as a substitute for petrochemicals. In this regard, considerable attention is drawn to natural gas as an alternative source of raw materials for petrochemical industries.

According to the annual Statistical Review of World Energy - 2018, published by British Petroleum (BP) at the end of 2017, proven natural gas reserves in the world are estimated at 193.5 trillion cubic meters.

Kazakhstan ranks $15^{\text {th }}$ in the world and $4^{\text {th }}$ in the CIS of natural gas reserves. The prospects for the development of the global gas processing industry are associated with the creation and introduction of new catalytic environmentally friendly technologies for producing of olefins, based on production of polymers, alcohols and motor fuels. Gas processing plants in Kazakhstan are currently engaged mainly in the purification of gases from water, impurities of carbon dioxide and hydrogen sulfide for their use for domestic purposes. This situation is associated with the lack or absence of new catalytic technologies for the directed processing of light $\mathrm{C}_{1}-\mathrm{C}_{4}$ alkanes. There are no production facilities for the production of olefins, plastics, motor fuels and other products whose demand is met by imports. Therefore, an important task is the intensive development of the industrial processing of light hydrocarbon raw materials, the reserves of which far exceed oil reserves.

It is known that natural gas is $90 \%$ methane. Oxidative dimerization of methane to ethylene, which allows obtaining a number of petrochemical products, such as polyethylene, polystyrene and many other chemical products, is of considerable interest. This is primarily due to the low cost of methane compared to other hydrocarbons [1]. Development of new efficient catalysts for the selective oxidation of light alkanes is still at the research and development stage [2-5].

In the work of Karakaya [6], the $\mathrm{Mn} / \mathrm{Na}_{2} \mathrm{WO}_{4} / \mathrm{SiO}_{2}$ catalyst was studied for the oxidative dimerization of methane. The catalyst was prepared by impregnation methods. The influence of temperature, volumetric rate and the ratio of reaction gases were investigated. It is determined that methane conversion is $38 \%$ at a volume rate of $390 \mathrm{~h}^{-1}$. The maximum ethylene yield was $16 \%$ at $750^{\circ} \mathrm{C}$ and a gas ratio of $\mathrm{CH}_{4} / \mathrm{O}_{2}=2$.

In [7] Sr-Al, La-Sr-Al and $\mathrm{Na}_{2} \mathrm{WO}_{4}-\mathrm{Mn} / \mathrm{SiO}_{2}$ series of catalysts were prepared by solution combustion synthesis (SCS). The activity of catalysts was investigated at $450-850^{\circ} \mathrm{C}$ and $\mathrm{CH}_{4}: \mathrm{O}_{2}: \mathrm{N}_{2}=32: 8: 10$ ratio, the linear velocity of gases was $50 \mathrm{~mL} /$ min. During the experiments, it was determined that catalysts were not active in the temperature range of $450-600^{\circ} \mathrm{C}$. The $\mathrm{Sr}-$ Al series of catalysts, where $\mathrm{Sr} / \mathrm{Al}=1.25$, were active. It was found that the maximum yield of $\mathrm{C}_{2}$ hydrocarbons on the $\mathrm{Sr} /$ $\mathrm{Al}=1.25$ catalyst at $\sim 800^{\circ} \mathrm{C}$ was $11.5 \%$ with $\mathrm{C}_{2} \mathrm{H}_{4} / \mathrm{C}_{2} \mathrm{H}_{6}=4.5$ ratio. For each catalyst of the La-Sr-Al series, the $\mathrm{C}_{2}$ hydrocarbons yield and ethylene/ethane ratio were measured over a wide temperature range. The highest ethylene yield of $12.3 \sim 13.0 \%$ was achieved at $720^{\circ} \mathrm{C}$, and the $\mathrm{C}_{2} \mathrm{H}_{4} / \mathrm{C}_{2} \mathrm{H}_{6}=1.7$ and 1.6 ratios, respectively. It was found that the $10 \% \mathrm{Na}_{2} \mathrm{WO}_{4}-5 \% \mathrm{Mn} / \mathrm{SiO}_{2}$ catalyst was the most highly active and selective one which provides the maximum yield of $\mathrm{C}_{2}$ hydrocarbons at $750^{\circ} \mathrm{C}$ (21\%) with the $\mathrm{C}_{2} \mathrm{H}_{4} / \mathrm{C}_{2} \mathrm{H}_{6}=2$ ratio. 
In [8] the $\mathrm{Mn}-\mathrm{Ce}-\mathrm{Na}_{2} \mathrm{WO}_{4} / \mathrm{SiO}_{2}$ catalysts prepared by the impregnation method were investigated for oxidative dimerization of methane. In particular, due to the double advantages of the tubular membrane reactor, a high methane conversion of $60.7 \%$ with selectivity of $\mathrm{C}_{2+} 41.6 \%$, ethylene/ ethane ratio of $5.8 \%$ and ethylene yield of $19.4 \%$ at a volumetric rate of gas hourly space velocity $(\mathrm{GHVV})=6050 \mathrm{ml} \cdot \mathrm{g}^{-1} \cdot \mathrm{h}^{-1}$ was achieved.

It is known that self-propagating high-temperature synthesis (SHS) contributes to the production of catalytically active, heat-resistant, nanostructured and promising composite materials. In the present work, the catalysts tested in the process of oxidative conversion of methane into important petrochemical products were prepared by the method of combustion in a solution.

\section{Experiment}

\subsection{Catalyst preparation}

The experimental part presents the results of the study of the activity of the following catalysts:

$1.5 \% \mathrm{~K}-3.5 \% \mathrm{Mn} / \mathrm{AlSi}$;

$1.5 \% \mathrm{~K}-3.5 \% \mathrm{Mn} / \mathrm{AlSi}+50 \%$ urea;

$10 \% \mathrm{~K}-30 \% \mathrm{Mn}-10 \% \mathrm{Nb} / 50 \%$ glycine.

The catalytic systems were synthesized by the method of impregnation in air and by solution combustion synthesis.

The developed compositions of catalysts were prepared by capillary impregnation of mixed aqueous solutions of metal nitrate salts supported on carriers by moisture capacity, followed by drying at $200^{\circ} \mathrm{C}$ for $2 \mathrm{~h}$. Calcinations of samples at $500^{\circ} \mathrm{C}$ for $2 \mathrm{~h}$ in air was carried out for decomposition of supported metal salts and corresponding volatilization of nitrates from the catalyst surface.

The catalysts using the SCS method were prepared [9-11]. Thus, certain amounts of nitrates of the corresponding salts were weighed to prepare a catalyst. These salts are pre-ground in an agate mortar and then mixed in a porcelain dish. Then 10 $\mathrm{mL}$ of distilled water is gradually added to this mixture of salts; the mixture is stirred in air for several minutes until complete dissolution.

The muffle furnace was previously turned on to the required temperature (in our case, up to $500^{\circ} \mathrm{C}$ ). The prepared mixture from a porcelain cup is transferred to a $200 \mathrm{~mL}$ heatresistant glass beaker and placed in a heated muffle furnace. After 2-3 min with an incomplete opening of the door of the muffle furnace, it is visually possible to observe burning in the solution, at which this mixture rises along the walls of the glass during rapid boiling. Urea and glycine were added to the composition of SCS catalysts to improve the combustion process. The presence of glycine or urea in the composition of catalyst contributes to a change in the color of solution into brown color during combustion. Then the glass is cooled in air, and the finished catalyst is placed in glass cups.

2.2 Characterization techniques

Analysis of the initial mixture and the reaction products was performed using "Chromos GC-1000" (Russia) chromatograph, which was equipped with packed and capillary columns. The packed column is used for the analysis of $\mathrm{H}_{2}, \mathrm{O}_{2}$, $\mathrm{N}_{2}, \mathrm{CH}_{4}, \mathrm{C}_{2} \mathrm{H}_{6}, \mathrm{C}_{2} \mathrm{H}_{4}, \mathrm{C}_{3}-\mathrm{C}_{4}$ hydrocarbons, $\mathrm{CO}$ and $\mathrm{CO}_{2}$. A capillary column is used to analyze liquid organic substances, such as alcohols, acids, aldehydes, ketones and aromatic hydrocarbons. Temperature of the detector by thermal conductivity $-200^{\circ} \mathrm{C}$, evaporator temperature $-280^{\circ} \mathrm{C}$, column temperature $-40^{\circ} \mathrm{C}$. The speed of the carrier gas (Ar) is $10 \mathrm{~mL} / \mathrm{min}$. The chromatographic peaks were calculated from the calibration curves plotted for the respective products using the "Chromos" software for pure substances. Based on the measured areas of the peaks corresponding to the amount of the introduced substance, a calibration curve $V=f(S)$ was constructed, where $V$ - amount of substance in $\mathrm{mL}, S$ - peak area in $\mathrm{cm}^{2}$. Concentrations of the obtained products were determined on the basis of the obtained calibration curves. The balance of regulatory substances and products was $\pm 3.0 \%$.

\subsection{Physico-chemical methods}

The specific surface area and measurement of the pore distribution of the developed catalysts were studied by the BET method (Bronauer-Emmett-Teller) on a GAPP V-Sorb 2800 analyzer (China). Nitrogen with helium was used as carrier gas. BET method was carried out at Advanced Ceramics and Composites Laboratory, Institute of Nanoscience and Nanotechnology NCSR “Demokritos" (Athens, Greece). Nitrogen with helium was used as carrier gas.

Morphology, particles size, chemical composition of initial and worked out catalysts were performed on transmission electron microscope TEM-125K with enlargement up to 66000 times by replica method with extraction and micro diffraction. Carbonic replicas were sputtered in universal vacuum station, and carrier of catalysts was dissolved in HF. Identification of micro diffraction patterns was carried out by means of ASTM cart index (Ukraine).

Natural gas with a methane volume of at least $99.99 \%$ (LLC “Cryogen", Kazakhstan) is the main object of study.

\section{Results and Discussion}

The paper presents data of activity of $1.5 \% \mathrm{~K}-3.5 \% \mathrm{Mn} / \mathrm{AISi}$ catalyst prepared by impregnation for the oxidative conversion of the $34 \% \mathrm{CH}_{4}+17 \% \mathrm{O}_{2}+49 \% \mathrm{Ar}$ mixture at the volumetric rate of $6500 \mathrm{~h}^{-1}$. As can be seen from Figure 1, the yield of the reaction products increases with increasing the reaction temperature from 650 to $900^{\circ} \mathrm{C}$.

The formation of products of partial oxidation $-\mathrm{H}_{2}$ and $\mathrm{CO}$, complete oxidation - $\mathrm{CO}_{2}$, and the target reaction products $\mathrm{C}_{2} \mathrm{H}_{6}$ and $\mathrm{C}_{2} \mathrm{H}_{4}$ is observed in the oxidative conversion of methane. It should be noted that the process goes towards the formation of $\mathrm{H}_{2}$ and $\mathrm{CO}$. The yields of products increase with increasing reaction temperature. $\mathrm{CO}_{2}$ is produced in smaller amounts, the yield of which also increases with increasing temperature. The yield of ethane and ethylene does not exceed $5 \%$ at all temperatures. 


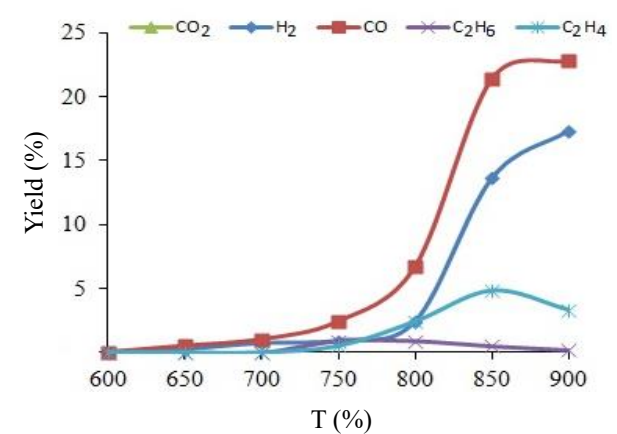

Figure 1 - Effect of a reaction temperature on the product yield of the oxidative conversion of methane on $1.5 \% \mathrm{~K}-3.5 \% \mathrm{Mn} / \mathrm{AlSi}$ catalyst

The active phase of $1.5 \% \mathrm{~K}-3.5 \% \mathrm{Mn}$ was introduced into AlSi+50\% urea mixture, followed by preparation of catalyst by SCS method for oxidative conversion of $66 \% \mathrm{CH}_{4}+34 \% \mathrm{O}_{2}$ mixture at $\mathrm{CH}_{4}: \mathrm{O}_{2}=2: 1$ ratio and $6500 \mathrm{~h}^{-1}$ space velocity without diluting the reaction mixtures with argon. As can be seen from Figure 2, the yield of reaction products increases with increasing the reaction temperature from 650 to $900^{\circ} \mathrm{C}$. In this case, $\mathrm{H}_{2}$, $\mathrm{CO}$, and $\mathrm{CO}_{2}$, the yield of which increases with increasing reaction temperature, are also the main reaction products. The yield of ethylene also does not exceed $5 \%$ at all temperatures.

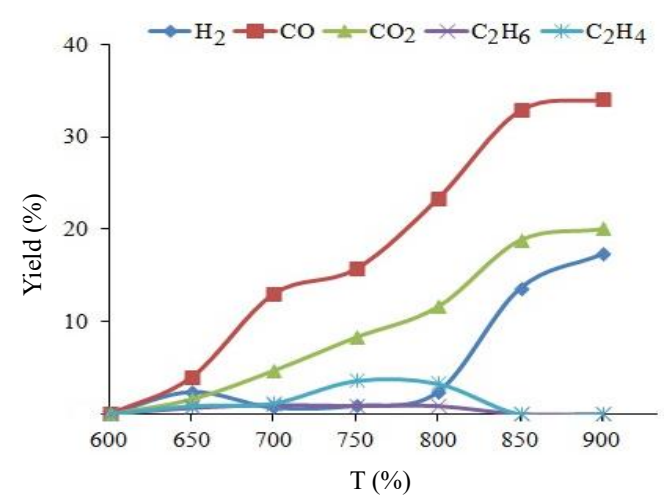

Figure 2 - Effect of reaction temperature on the product yield of the oxidative conversion of methane on $1.5 \% \mathrm{~K}-3.5 \% \mathrm{Mn} /$ $\mathrm{AlSi}+50 \%$ urea catalyst

Data on the activity of the developed three-component $10 \% \mathrm{~K}-30 \% \mathrm{Mn}-10 \% \mathrm{Nb} / 50 \%$ glycine catalyst prepared by the SCS method for oxidative conversion of $41.8 \% \mathrm{CH}_{4}+16.2 \% \mathrm{O}_{2}+42 . \% \mathrm{Ar}$ mixture at a space velocity of $3500 \mathrm{~h}^{-1}$ and $\mathrm{CH}_{4}: \mathrm{O}_{2}=2.5: 1.0$ ratio will be given. As can be seen from Figure 3 , the three-component composition with the addition of niobium showed good activity in relation to the formation of olefins compared with the two-component compositions of catalysts prepared in various ways. The yield of
$\mathrm{C}_{2} \mathrm{H}_{4}$ and $\mathrm{C}_{2} \mathrm{H}_{6}$ also increases with an increase in the reaction temperature from 600 to $800^{\circ} \mathrm{C}$. At a temperature of $800^{\circ} \mathrm{C}$, the yield of $\mathrm{C}_{2} \mathrm{H}_{4}$ passes through a maximum and decreases again with increasing temperature to $900^{\circ} \mathrm{C}$. The yields of $\mathrm{H}_{2}, \mathrm{CO}$ and $\mathrm{CO}_{2}$ slightly change with increasing temperature and vary within 2-3\%. Thus, the optimal temperature for the formation of $\mathrm{C}_{2} \mathrm{H}_{4}$ at which the yield is $14.3 \%$.

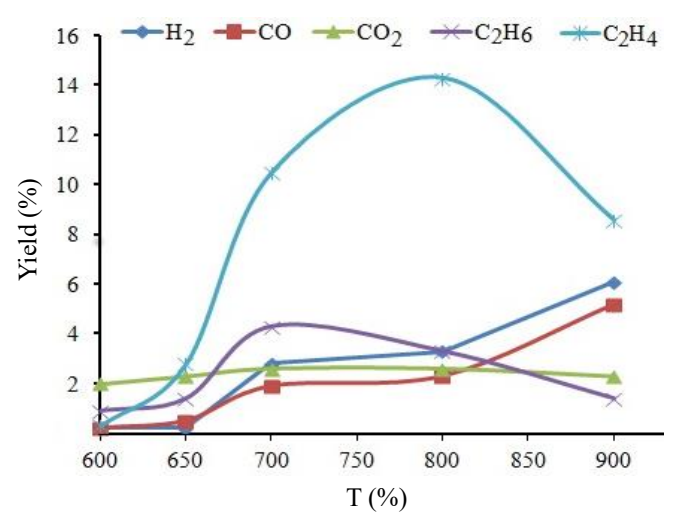

Figure 3 - Effect of reaction temperature on the product yield of oxidative conversion of methane on $10 \% \mathrm{~K}-30 \% \mathrm{Mn}$ $10 \% \mathrm{Nb} / 50 \%$ glycine catalyst

Thus, the activity of the developed two- and threecomponent catalytic systems prepared by impregnation and SCS method in the oxidative conversion of the methane of natural gas was investigated. It was established that $10 \% \mathrm{~K}-30 \% \mathrm{Mn}-10 \% \mathrm{Nb} / 50 \%$ glycine catalyst prepared by the SCS method is the most active in formation of $\mathrm{C}_{2} \mathrm{H}_{4}$ among the studied compounds. It was found that $800^{\circ} \mathrm{C}$ is the optimum temperature for the formation of $3.3 \% \mathrm{C}_{2} \mathrm{H}_{6}$ and $14.3 \% \mathrm{C}_{2} \mathrm{H}_{4}$ in the process of oxidative conversion of the mixture $41.8 \% \mathrm{CH}_{4}+16.2 \% \mathrm{O}_{2}+42 \%$ Ar with a ratio of $\mathrm{CH}_{4}: \mathrm{O}_{2}=2.5: 1.0$ and $\mathrm{a}$ space velocity of $3500 \mathrm{~h}^{-1}$.

In addition, the methods for synthesis of the developed catalysts were determined, and the physicochemical characteristics of the catalysts were established. Developed applied K-Mn catalyst was studied by the BET method (Figures 4 and 5).

It is known that five types of hysteresis loops were identified and correlated with various pore shapes by De Boer. Hysteresis type A corresponds to cylindrical supports, type B is associated with slit-like pores, hysteresis type $C$ and $D$ are wedge-shaped pores, and hysteresis type $\mathrm{E}$ is produced by the pores of the neck of the bottle. The isotherm of adsorption and description of applied K-Mn catalyst shown in Figure 4 correspond to the first type of hysteresis $A$ [12].

From the data of Figure 5, it can be seen that a significant amount of pores have a size of up to $10 \mathrm{~nm}$. This, in turn, is an important characteristic of catalyst, on the basis of which it can be concluded that the developed catalyst is nanoscale. 


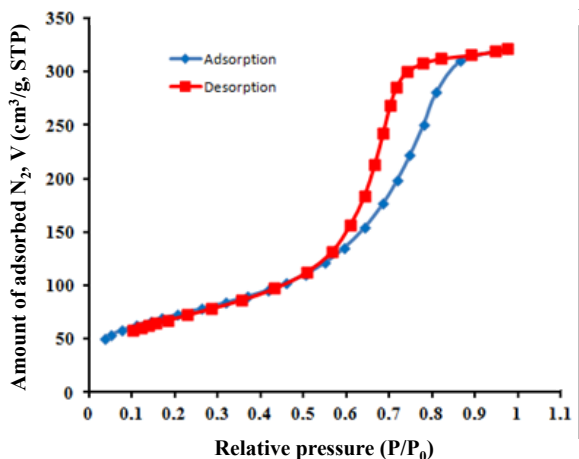

Figure 4 - Isotherm of adsorption and desorption of applied K-Mn catalyst

This conclusion is also confirmed by electron microscopic studies of catalysts. Figure 6 shows the electron microscopy and electron microdiffraction data of the accumulation of particles whose sizes vary from $5-10 \mathrm{~nm}$ to $50 \mathrm{~nm}$ or more. The microdiffraction (a) pattern is represented by symmetric and separate reflexes and can be related to the phase mixture: $\alpha-\mathrm{KO}_{2}$ (JCPDS, 8-351), $\varepsilon-\mathrm{MnO}_{2}$ (JCPDS, 12-141), KAIO ${ }_{2}$ (JCPDS, 2-897), $\mathrm{Mn}_{5} \mathrm{Al}_{4} \mathrm{Si}_{5} \mathrm{O}_{21} \cdot 3 \mathrm{H}_{2} \mathrm{O}$ (JCPDS, 18-1286) and perhaps $\mathrm{MnAl}_{2} \mathrm{O}_{4}$ Galaxite (JCPDS, 29-880), $\mathrm{K}_{2} \mathrm{Si}_{4} \mathrm{O}_{9}$ (JCPDS, 26-1463), $\mathrm{Al}_{2} \mathrm{Mn}_{4} \mathrm{O}_{8}$ (JCPDS, 16-205)

Figure $6 \mathrm{~b}$ shows small accumulations of small dense particles with a size of $4-5 \mathrm{~nm}$. The microdiffraction pattern is represented by a small set of weak diffuse rings and can be attributed to a mixture of phases: $\alpha-\mathrm{Mn}_{2} \mathrm{O}_{3}$ (JCPDS, 24-508) and $\mathrm{K}_{2} \mathrm{O}_{2}$ (JCPDS, 32-827). Figure $6 \mathrm{c}$ shows large translucent and

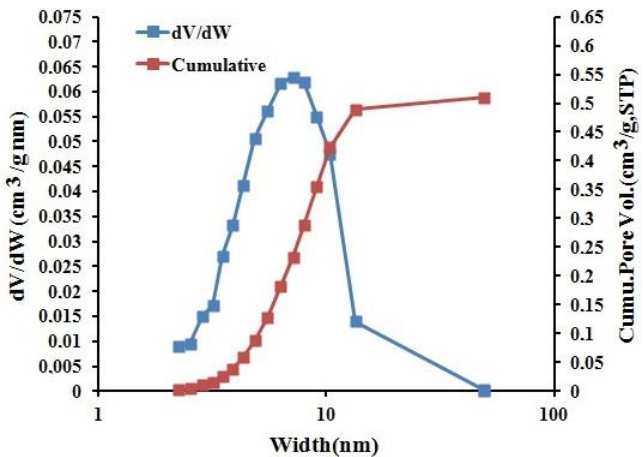

Figure 5 - Differential dependence of pore size distribution on applied K-Mn catalyst

dense particles with sizes ranging from $50-100 \mathrm{~nm}$ to $200 \mathrm{~nm}$ or more. The microdiffraction pattern is represented by a small set of reflexes and can be attributed to a mixture of phases: $\alpha-\mathrm{K}_{2} \mathrm{SiO}_{3}(\mathrm{JCPDS}, 31-1076), \mathrm{Mn}_{5}\left(\mathrm{SiO}_{4}\right)_{2}(\mathrm{OH})_{2}$ Allghanyite (JCPDS, 22-726), $\beta-\mathrm{MnO}_{2}$ Pyrolusite (JCPDS, 24-735), $\epsilon-\mathrm{MnO}_{2}$ Akhtanslite (JCPDS, 30-820) and $\mathrm{K}_{0.47} \mathrm{Mn}_{0.94} \mathrm{O}_{2}$ (JCPDS, 30-950).

Thus, the influence of technological parameters of reaction on the yield of target products was established. The study of catalytic oxidative conversion of the main components of natural gas is methane was carried out on the developed catalytic systems by varying the reaction temperature, space velocity and ratio of the main gases in reaction mixture in order to obtain the optimal amount of desired reaction products. Process parameters on an effective catalyst in an integrated plant were optimized.
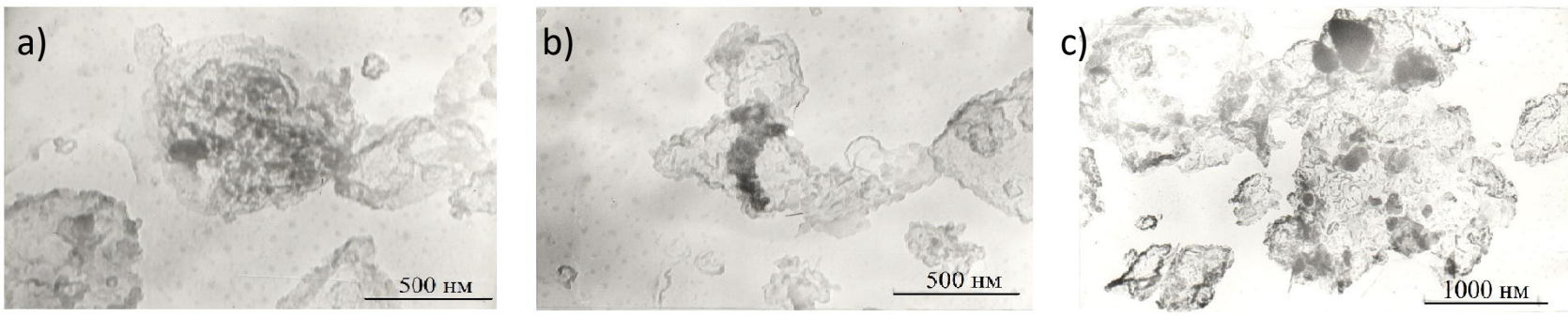

Figure 6 - Electron microscopic images of the 5\% K-Mn catalyst (x 66000)

\section{Conclusions}

Thus, synthesis methods were developed, and physicochemical characteristics of catalysts were established. Technological parameters of the process, conducted in an integrated automated laboratory setup, were optimized.

It was established that $10 \% \mathrm{~K}-30 \% \mathrm{Mn}-10 \% \mathrm{Nb} / 50 \%$ glycine catalyst prepared by SCS method is active for production of $14.3 \% \mathrm{C}_{2} \mathrm{H}_{4}$ in oxidative conversion of $41.8 \% \mathrm{CH}_{4}+16.2 \% \mathrm{O}_{2}+$ $42 \% \mathrm{Ar}$ at $800^{\circ} \mathrm{C}$ and space velocity of $3500 \mathrm{~h}^{-1}$.
It follows from the results that it is possible to optimize the process of oxidative conversion of methane by selecting the optimal technological parameters of the reaction and improving the composition of the catalysts.

\section{Acknowledgments}

The work was supported by the Ministry of Education and Science of the Republic of Kazakhstan (Project No BR05236739). 


\section{References (GOST)}

1 Gambo Y., Jalil A.A., Triwahyono S., Abdulrasheed A.A. Recent advances and future prospect in catalysts for oxidative coupling of methane to ethylene: A review // Journal of Industrial and Engineering Chemistry. - 2018. - Vol.59. - P.218-229.

2 Dury F., Gaigneaux E.M., Ruiz P. The active role of $\mathrm{CO}_{2}$ at low temperature in oxidation processes: the case of the oxidative dehydrogenation of propane on $\mathrm{NiMoO}_{4}$ catalysts // Applied Catalysis A: General. - 2003. - Vol.242, Is.1. - P.187-203

3 Ozkan U.S., Watson R.B. The structure-function relationships in selective oxidation reactions over metal oxides // Catalysis Today. - 2005. - Vol.100. - P.101-114.

4 Dimitratos N., Vedrine J.C. Study of Ga modified $\mathrm{Cs}_{2.5} \mathrm{H}_{1.5} \mathrm{PV}_{1} \mathrm{Mo}_{11} \mathrm{O}_{40}$ heteropolyoxometallates for propane selective oxidation // Journal of Molecular Catalysis A: Chemical. - 2006. - Vol.255, Is.1-2. -P.184-192.

5 Routray K., Reddy K.R.S.K., Deo G. Oxidative dehydrogenation of propane on $\mathrm{V}_{2} \mathrm{O}_{5} / \mathrm{Al}_{2} \mathrm{O}_{3}$ and $\mathrm{V}_{2} \mathrm{O}_{5} / \mathrm{TiO}_{2}$ catalysts: understanding the effect of support by parameter estimation // Applied Catalysis A: General. - 2004. - Vol.265, Is.1. - P.103-113.

6 Karakaya C., Zhu H., Loebick C., Weissman J.G., Kee R.J. A detailed reaction mechanism for oxidative coupling of methane over $\mathrm{Mn} / \mathrm{Na} 2 \mathrm{WO}$ /SiO2 catalyst for non-isothermal conditions // Catalysis Today. - 2018. - Vol.312. - P.10-22.

7 Ghose R., Hwang H.T., Varma A. Oxidative coupling of methane using catalysts synthesized by solution combustion method // Applied Catalysis A: General. - 2013. - Vol.452. - P.147-154.

8 Liu K., Zhao J., Zhu D., Meng F., Kong F., Tang Y. Oxidative coupling of methane in solid oxide fuel cell tubular membrane reactor with high ethylene yield // Catalysis Communications. - 2017. - Vol.96. - P.23-27.

9 Tungatarova S.A., Xanthopoulou G., Karanasios K., Baizhumanova T.S., Zhumabek M., et al. New Composite materials prepared by solution combustion synthesis for catalytic reforming of methane // Chemical Engineering Transactions. - 2017. - Vol.61. P.1921-1926.

10 Tungatarova S.A., Zheksenbaeva Z.T., Baizhumanova T.S., Zhumabek M., Sarsenova R.O., et al. Selective polyoxide catalysts for synthesis of ethylene from natural gas // Chemical Engineering Transactions. - 2018. - Vol.70. - P.1927-1932.

11 Xanthopoulou G., Karanasios K., Tungatarova S., Baizhumanova T., Zhumabek M., et al. Catalytic methane reforming into synthesis gas over developed composite materials prepared by combustion synthesis // Reaction Kinetics, Mechanisms and Catalysis. - 2019. - Vol.126, Is.2. - P.645-661.

12 Nie B., Liu X., Yang L., Meng J., Li X. Pore structure characterization of different rank coals using gas adsorption and scanning electron microscopy // Fuel. - 2015. - Vol.158. -P.908-917.

\section{References}

1 Gambo Y, Jalil AA, Triwahyono S, Abdulrasheed AA (2018) J Ind Eng Chem 59:218-229. https://doi.org/10.1016/j.jiec.2017.10.027

2 Dury F, Gaigneaux EM, Ruiz P (2003) Appl Catal A-Gen 242:187-203. https://doi.org/10.1016/S0926-860X(02)00516-1

3 Ozkan US, Watson RB (2005) Catal Today 100:101-114. https://doi.org/10.1016/j.cattod.2004.12.018

4 Dimitratos N, Vedrine JC (2006) J Mol Catal A-Chem 255:184-192. https://doi.org/10.1016/j.molcata.2006.03.075

5 Routray K, Reddy KRSK, Deo G (2004) Appl Catal A-Gen 265:103-113. https://doi.org/10.1016/j.apcata.2004.01.006

6 Karakaya C, Zhu H, Loebick C, Weissman JG, Kee RJ (2018) Catal Today 312:10-22. https://doi.org/10.1016/j.cattod.2018.02.023

7 Ghose R, Hwang HT, Varma A (2013) Appl Catal A-Gen 452:147-154. https://doi.org/10.1016/j.apcata.2012.11.029

8 Liu K, Zhao J, Zhu D, Meng F, Kong F, Tang Y (2017) Catal Commun 96:23-27. https://doi.org/10.1016/j.catcom.2017.03.010

9 Tungatarova SA, Xanthopoulou G, Karanasios K, Baizhumanova TS, Zhumabek M, et al (2017) Chem Engineer Trans 61:19211926. https://doi.org/10.3303/CET1761318

10 Tungatarova SA, Zheksenbaeva ZT, Baizhumanova TS, Zhumabek M, Sarsenova RO, et al 2018) Chem Engineer Trans 70:19271932. https://doi.org/10.3303/CET1870322

11 Xanthopoulou G, Karanasios K, Tungatarova S, Baizhumanova T, Zhumabek M, et al (2019) Reaction Kinetics, Mechanisms and Catalysis 126:645-661. https://doi.org/10.1007/s11144-019-01541-9

12 Nie B, Liu X, Yang L, Meng J, Li X (2015) Fuel 158:908-917. https://doi.org/10.1016/j.fuel.2015.06.050 